\title{
QUANTITATIVE AND QUALITATIVE EFFECTS OF SOME INORGANIC AND ORGANIC FERTILIZERS ON MAIZE (ZEA MAYSL.) UNDER ALLUVIAL SOIL
}

\author{
Enas E. Yousif, Eman H. Abd El-Azeiz and K.E.M. Nassar \\ Soil Fertility and Plant Nutrition Research Department: Soils, Water and \\ Environment Research Institute; Agricultural Research Center: Giza; Egypt
}

Received: Oct. 23,2021

Accepted: Nov. 9, 2021

\begin{abstract}
Two field experiments were conducted at the Experimental Farm of Tag El- Ezz , Dakahlia governorate $\left(30^{\circ} 5911 \mathrm{~N}\right.$ latitude, E $31^{\circ} 5811$ longitude) ,ARC, Egypt during the two growing summer seasons of 2020 and 2021 as sake of studying the possibility of partially substituting for the amount of inorganic NPK fertilizers required for maize plants using compost and/or vermicompost and their effects on growth, yield and nutrients uptake of maize plants (Single cross 10 variety) under the alluvial soil conditions. Experiments were laid out in split plot design with three replicates. However, main plots were affected for four rates of inorganic NPK fertilizers i.e.; without, $50 \%, 75 \%$ and $100 \%$ of the recommended dose (RD)) whereas, four organic fertilizers namely without, compost (C); (5 ton fed-1), vermicompost (VC); (0.5 ton fed-1) as well as half compost and half vermicompost (mix)) were randomly distributed in the sub plots. Results showed that:

1- Application of inorganic NPK fertilizers at 100\% RD recorded the highest values of growth parameters, yield and nutrients uptake by maize grains in the two investigated seasons
\end{abstract}

2- Using organic fertilizers i.e. compost and lor vermicompost caused a significant effect on all growth parameters, yield and nutrients uptake. In this respect, V.C. attained the superiority impacts followed by mix and lately C compared with control (without adding NPK fertilizers).

3- The addition of inorganic NPK fertilizers at $100 \%$ RD and organic V.C. had positive impacts on maize growth parameters, yield and nutrients uptake better than the application of inorganic NPK fertilizers at $100 \%$ RD singly under the two investigated seasons.

4- Dual application of inorganic NPK fertilizers at 100\% RD and organic C treatment application achieved the highest values of available NPK in the soil post harvesting.

5- Economically using inorganic NPK fertilizers at $75 \%$ RD and $C$ recorded the highest net return and benefit cost ratio (BCR). So, it could be a good alternative to other treatments, save $25 \%$ of inorganic NPK fertilizers and viable option for enhancing crop yield and farmers income.

Key words: Inorganic, Organic, Compost, Vermicompost, Maize.

\section{INTRODUCTION}

Maize is one of the most important cereals in the world and the third one after wheat and rice (FAO, 2009). It is considered as a staple food for humans in the most developing countries especially Africa, also it used as an animal feed and a low price raw material for several industrial processes. (Adetiminrin et al., 2008). Increasing the national production of maize is one of the most important agricultural goals in Egypt to face the human and animal needs. Soil fertility is an important for achieving high crop yields over a period 
of time. Fertilizer applications have usually been the major means of supplying plant nutrients (Fageria and Baligar, 2005).

The chemical (inorganic) fertilizers contain nitrogen, phosphorus and potassium in forms readily utilized by plants. Nitrogen is a major nutrient that responsible for protoplasm synthesis, rapid cell division and important for plant growth and yield production where it is a constituent of amino acids, nucleic acids and enzymes (Singh et al., 2003).

Phosphorous has a vital role in several physiological processes within plant such as releasing energy during cellular, photosynthesis, respiration and several other processes in living plants (Rai, 2006).

Potassium adjust osmotic potential and water uptake. Moreover, it has a responsible role in activating most of enzyme systems that regulate photosynthesis, water use efficiency, movement nitrogen uptake and protein production (Singh et al., 2003).

Excessive use of inorganic fertilizers has adverse effects in the soil i.e. soil physical degradation, imbalance of soil nutrient and declining soil fertility as well as food quality (Makinde and Ayoola, 2010). Alternate fertilizers were used such as organic fertilizers that more safety on healthy of human and have a positive effects on soil properties such as improving soil structure and increasing water-holding capacity of the soil (Edwards et al., 2004).

\footnotetext{
Compost is a biologically decomposed organic material by thermophilic and mesophilic microorganisms (Bastida et al., 2010). Compost positively impact on improving soil properties, increasing soil organic matter, enhancing microbial activities and improving soil structure. (Gao et al., 2010).
}

Vermicomposts are organic materials broken down in a mesophilic process by earthworms. Earthworms transform inorganic nutrients to forms more available, also provide organic material with auxins, cytokinins and gibberellins via their secretions and finally produced fully stabilized organic soil amendments with low C: $\mathrm{N}$ ratios (Ramasamy and Kathirvelu, 2011).

Vermicompost application improves the soil fertility, adjust the soil temperature and increases the availability of nutrients required by plants (Dignac et al., 2017).

Using inorganic and organic fertilizers simultaneously increased yield and crop productivity as well as improved soil properties. Yet, combination of organic fertilizers and inorganic ones increase maize yield via increasing soil productivity and raising the efficiency of the used fertilizer. (Abd El-Gawad and Morsy, 2017).

So, the present investigation aimed to raising the efficiency of the adding mineral fertilizers and saving their amounts required for maize plants via partial substituting by some organic fertilizers (compost and vermicompost) and integrated impacts of their combinations on growth, yield and nutritive contents of maize. Available nutrients in the soils after harvesting were also taken into consideration.

\section{MATERIALS AND METHODS}

\section{Locations of study}

The present study was established at Tag El-Ezz agricultural research station, Dakahlia governorate $\left(30^{\circ} 5911 \mathrm{~N}\right.$ latitude, E 31 581 ll longitude), ARC; Egypt during the two summer seasons of 2020 and 2021 to study the impact of partially substituting the amount of integrated inorganic NPK fertilizers required for maize using compost, vermicompost and 
mix of them on growth, yield and nutrients uptake of maize plants under alluvial soil conditions.

Each plot area was $19.2 \mathrm{~m}^{2}$ included four rows $6.00 \mathrm{~m}$ long and $0.80 \mathrm{~m}$ apart between rows. The maize grains variety single cross 10 (SC10) were sown at a rate of $10 \mathrm{kgfed}^{-1}$ on 7 th and $1^{\text {st }}$ June on summer seasons of 2020 and 2021 respectively. The experiment was irrigated six times, the first one at 21 days after sowing and the others were every 15 days. The plants were thinned to one plant/ hill before the first irrigation.

Nitrogen fertilizer as urea $(46.5 \% \mathrm{~N})$, was added in three equal doses before first, second and third irrigations. Potassium was added as potassium sulphate $\left(48 \% \mathrm{~K}_{2} \mathrm{O}\right)$ in one dose (after 45 days from sowing). Super phosphate $\left(15 \% \mathrm{P}_{2} \mathrm{O}_{5}\right)$ was added to all plots as a single dose and well mixed with such surface layer. Compost and vermicompost were thoroughly mixed with $\mathbf{0 - 3 0} \mathrm{cm}$ soil surface layer two weeks before sowing.

Soil samples from $\mathbf{0 - 3 0} \mathrm{cm}$ soil surface layer were randomly collected before planting. Soil physical and chemical characteristics as well as nutrients status of the experimental sites were determined according to Page et al., (1982) and Klute (1986) as shown in Table (1). Samples from compost and vermicompost were analyzed according to methods described by Cottenie (1982) as shown in Table (2).

Table (1): Soil physical and chemical analyses under the two investigated seasons

\begin{tabular}{|c|c|c|}
\hline Soil Characteristics & & \\
\hline I. Physical properties: & $1^{\text {st }}$ season & $2^{\text {nd }}$ seasons \\
\hline \multicolumn{3}{|l|}{ Particle size distribution } \\
\hline Sand & 19.31 & 19.33 \\
\hline Silt & 37.92 & 38.02 \\
\hline Clay & 42.77 & 42.65 \\
\hline Soil Texture Class & Clay & Clay \\
\hline \multicolumn{3}{|l|}{ II. Chemical properties: } \\
\hline $\mathrm{pH},[1: 2.5$ soil water suspension] * & 8.00 & 8.02 \\
\hline$E C,\left[\text { soil extract, } \mathrm{dS}^{-1}\right]^{* *}$ & 4.31 & 4.30 \\
\hline \multicolumn{3}{|c|}{ Soluble cations, meq $100 \mathrm{~g}^{-1}$ soil) } \\
\hline $\mathrm{Ca}^{2+}$ & 8.58 & 8.60 \\
\hline $\mathrm{Mg}^{2+}$ & 7.30 & 7.28 \\
\hline $\mathrm{Na}^{+}$ & 23.09 & 23.12 \\
\hline $\mathrm{K}^{+}$ & 4.10 & 4.00 \\
\hline \multicolumn{3}{|l|}{ Soluble anions, meq $100 \mathrm{~g}^{-1}$ soil) } \\
\hline CO32- & - & - \\
\hline HCO3- & 1.98 & 2.00 \\
\hline Cl- & 19.61 & 19.50 \\
\hline SO42- & 21.48 & 21.50 \\
\hline \multicolumn{3}{|l|}{ III. Nutritional properties, $\mathrm{mg} \mathrm{kg}^{-1}$ : } \\
\hline $\mathbf{N}$ & 47.62 & 52.12 \\
\hline $\mathbf{P}$ & 9.15 & 9.92 \\
\hline $\mathrm{K}$, & 200.25 & 204.38 \\
\hline
\end{tabular}


Enas E. Yousif, Eman H. Abd El-Azeiz, et al.,

Table 2. Physical and chemical analyses of the used vermicompost (VC) and compost (C).

\begin{tabular}{l|c|c|}
\hline Properties & Vermicompost (VC) & Compost (C) \\
\hline $\mathrm{pH}, 1: 10$ & 7.52 & 6.42 \\
\hline $\mathrm{EC},(1: 10), \mathrm{dS} \mathrm{m}^{-1}$ & 2.70 & 3.75 \\
\hline \multicolumn{3}{|c|}{} \\
\hline O.M\% & 33.64 & 33.00 \\
\hline Organic carbon\% & 35.64 & 18.02 \\
\hline Total N\% & 2.35 & 1.42 \\
\hline C/N ratio & 15.16 & 12.73 \\
\hline \multicolumn{2}{|l}{} \\
\hline Total P\% & 2.14 & 0.44 \\
\hline Total K\% & 1.33 & 0.76 \\
\hline Fe mg kg & & 64.25 \\
\hline Mn mg kg & & 26.34 \\
\hline
\end{tabular}

\section{Experiment description:}

Each experiment included the impact of sixteen treatments resulting from the combinations of four inorganic NPK fertilizers levels (without, 50, 75 and $100 \%$ of the recommended dose (RD), $120 \mathrm{Kg} \mathrm{N}, 200 \mathrm{Kg} \mathrm{P}_{2} \mathrm{O}_{5}$ and $50 \mathrm{Kg} \mathrm{K} \mathrm{O}_{2}$. $\mathrm{fed}^{-1}$ ) as the main plots and four types of organic fertilizers (without, compost (C); ( 5 ton fed $^{-1}$ ), vermicompost (VC); ( 0.5 ton fed $^{-1}$ ) and half amount of compost+ half amount of vermicompost (mix)) as the sub plots on maize (Zea mays L.) var. SC10 plants growth, yield and nutrients uptake as well as available nutrients in the soil after maize harvesting. So, the experimental design was a split- plot in three replications.

\section{Data recorded}

\section{1- Growth Stage measurements:}

Plant samples were collected from each sub plot at maximum vegetative growth stage for measurement of some growth parameters (shoot height $(\mathrm{cm})$, plant fresh weight $\left(g\right.$ plant $\left.^{-1}\right)$ and plant dry weight (g plant $\left.{ }^{-1}\right)$ ). Chlorophyll a and chlorophyll b ( $\mathrm{mg} \mathrm{g}^{-1}$ fresh weight of leaf) were also determined using a method described by Nayek et al., (2014). Total N, $P$ and $K$ concentration were determined according to the methods described by Buresh (1982) and Chapman and Pratt (1961), respectively.

\section{2-Harvest stage measurements:}

At harvest, the following characters, Plant height $(\mathrm{cm})$, ear length $(\mathrm{cm})$, ear diameter $(\mathrm{cm})$, ear weight $(\mathrm{g}), 100$ kernel weight (g) and grain yield (ton fed ${ }^{-1}$ ) were recorded at randomly ten guarded plants from each plot. The yielded seeds were cleaned, crushed and digested to determine total $\mathrm{N}, \mathrm{P}$ and $\mathrm{K}$ percentages. Nutrients uptake was determined according to the following formula:

Nutrients uptake

kg fed $-1=$

Nutrient concentration $\mathrm{x}$ seed yield $(\mathrm{kg}$ fed - 1) 100

\section{3- Residual nutrients in soil:}

Surface soil samples $(0-30 \mathrm{~cm})$ from each sub plot were collected after harvesting to determine the available $\mathrm{N}, \mathrm{P}$ and $\mathrm{K}\left(\mathrm{mg} \mathrm{kg}^{-1}\right)$.

\section{Economics}

Total cost of cultivation and gross return were calculated on the basis of 
prevailing market rates for different practices and produces. The total cost of cultivation per feddan was subtracted from the gross income for computing net return from each treatment.

Net return $\left(£\right.$. fed $\left.^{-1}\right)=$ Gross return $\left(£\right.$. fed $\left.^{-1}\right)$ Cost of cultivation $\left(£\right.$. fed $\left.^{-1}\right)$

Benefit cost ratio (BCR) was calculated treatment wise as below.

Benefit Cost Ratio $($ BCR $)=\frac{\text { Gross return }}{\text { Cost of cultivation }}$

\section{Statistical analysis}

All data were subjected to statistical analysis according to Snedecor and Cochran (1980) and the means were compared using least significant difference at $5 \%$ level. Appropriate analyses of variance were performed for the two experiments according to Steel and Torrie (1984).

\section{RESULTS AND DISCUSSION}

1- Integrated effect of inorganic and organic fertilizers on some plant growth measurements.

Data tabulated in Table 3 show that maize vegetative growth parameters as: shoot height $(\mathrm{Cm})$; fresh weight (g plant $\left.^{-1}\right)$ and dry weight $\left(g\right.$ plant $\left.^{-1}\right)$ were significantly affected by all applied treatments during the two successive seasons.

It's clear that using inorganic NPK fertilizers at $100 \%$ RD gave the highest values of all previous studied parameters where the values were $(256.77,259.86)$ for shoot height, $(203.35,206.62)$ for fresh weight and $(42.72,49.85)$ for dry weight of maize plants comparing with the control (no addition). These results are in matching with those found by (Khan et al., 2011).

These results may be due to the positive impact of NPK nutrients on plant growth where they increase internodes numbers and length that increase shoot length as well as their role in promoting meristematic activities in plant (Hafez and Abdelaal, 2015).

Organic fertilizers sources enhancing values of shoot height, fresh weight and dry weight comparing with control treatment application. In this concern organic V.C. treatment recorded the highest values of shoot height (226.80, 230.78); fresh weight $(174.12,176.80)$ and dry weight $(36.15,41.61)$ comparing with other organic fertilizer sources in the two seasons, respectively. These results may be attributed to the enrichment of V.C. with organic matter which supply plant with essential nutrients for growth in available forms (Atiyeh et al., 2002).

Sinha et al., (2010) also found that V.C. application enhances maize growth from 50 to $100 \%$ over compost and 30 to $40 \%$ over inorganic fertilizers.

Its clear that, addition of inorganic NPK at $75 \%$ or $100 \%$ in combination with either organic compost or vermicompost gave values higher than that recorded by inorganic NPK at $100 \%$ RD singly. Addition of inorganic NPK fertilizers at $100 \%$ RD and organic V.C. recorded the highest values of maize shoot height by (268.20, 272.33), fresh weight by $(218.45$, $222.37)$ and dry weight by $(47.30,55.66)$ in the two investigated seasons comparing with those attained when application of NPK fertilizers at $\mathbf{1 0 0 \%}$ RD singly.

These increments may be due to the fact that organic and inorganic fertilizers enhance plant growth, increase length and internode numbers that increase plant height (Laekmariam and Gidago, 2012). Yet, vermicomposts have vital roles in enhancing soils quality via increasing microbial activity and microbial biomass that are key components in nutrient cycling and plant growth regulators production. These results are in matching with that concluded by Adamu et al., (2015). 
Enas E. Yousif, Eman H. Abd El-Azeiz, et al.,

Table 3. Integrated effect of inorganic and organic fertilizers on vegetative growth parameters of maize plants in the two successive seasons.

\begin{tabular}{|c|c|c|c|c|c|c|c|}
\hline \multirow{3}{*}{\multicolumn{2}{|c|}{ Treatments }} & \multirow{2}{*}{\multicolumn{2}{|c|}{$\begin{array}{c}\text { (cm) } \\
\text { Shoot height }\end{array}$}} & \multicolumn{4}{|c|}{ g plant $^{-1}$} \\
\hline & & & & \multicolumn{2}{|c|}{ Fresh weight } & \multicolumn{2}{|c|}{ Dry weight } \\
\hline & & $1^{\text {st }}$ & $2^{\text {nd }}$ & $1^{\text {st }}$ & $2^{\text {nd }}$ & $1^{\text {st }}$ & $2^{\text {nd }}$ \\
\hline \multicolumn{8}{|c|}{ Main : inorganic fertilizer rates } \\
\hline \multicolumn{2}{|c|}{0} & 155.07 & 158.56 & 108.55 & 110.03 & 21.22 & 22.63 \\
\hline \multicolumn{2}{|c|}{50} & 205.16 & 208.97 & 154.18 & 156.73 & 30.82 & 33.34 \\
\hline \multicolumn{2}{|c|}{75} & 243.74 & 246.40 & 183.47 & 185.36 & 36.96 & 43.04 \\
\hline \multicolumn{2}{|c|}{100} & 256.77 & 259.86 & 203.35 & 206.62 & 42.72 & 49.85 \\
\hline \multicolumn{2}{|c|}{$F$ test } & $\star * \star$ & $\star * * *$ & $* \star *$ & $\star * \star$ & 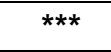 & $* \star *$ \\
\hline \multicolumn{2}{|c|}{ LSD at $0.05 \%$} & 1.82 & 0.499 & 0.119 & 0.286 & 0.321 & 0.180 \\
\hline \multicolumn{8}{|c|}{ Sub main: organic fertilizer sources } \\
\hline \multicolumn{2}{|c|}{0} & 200.49 & 203.06 & 147.80 & 149.91 & 28.92 & 32.13 \\
\hline \multicolumn{2}{|c|}{ C } & 213.52 & 216.96 & 160.31 & 162.13 & 32.49 & 36.03 \\
\hline \multicolumn{2}{|c|}{ V.C } & YrY,A. & $r r_{0}, V \Lambda$ & $T V \varepsilon, I Y$ & $I \vee \checkmark, \wedge$. & $r 4,10$ & $\{1, \pi$ \\
\hline \multicolumn{2}{|c|}{ Mix } & 219.92 & 222.99 & 167.32 & 169.90 & 34.16 & 39.09 \\
\hline \multicolumn{2}{|c|}{ F test } & $\star * \star$ & $* * *$ & $* \star *$ & $\star * \star$ & 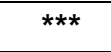 & $* \star \star *$ \\
\hline \multicolumn{2}{|c|}{ LSD at $0.05 \%$} & 1.33 & 0.942 & 0.0815 & 0.221 & 0.277 & 0.128 \\
\hline \multicolumn{8}{|c|}{ Interaction } \\
\hline \multirow{4}{*}{$\begin{array}{c}0 \\
\text { NPK }\end{array}$} & 0 & 146.40 & 149.32 & 93.25 & 95.22 & 18.30 & 20.36 \\
\hline & $\mathbf{C}$ & 152.33 & 156.26 & 103.52 & 102.14 & 19.87 & 18.65 \\
\hline & v.c & 166.30 & 168.33 & 122.18 & 125.46 & 24.50 & 27.28 \\
\hline & Mix & 155.26 & 160.33 & 115.27 & 117.33 & 22.24 & 24.28 \\
\hline \multirow{4}{*}{$\begin{array}{l}50 \% \\
\text { NPK }\end{array}$} & 0 & 186.26 & 188.14 & 145.33 & 146.28 & 27.92 & 27.92 \\
\hline & C & 201.42 & 206.28 & 152.65 & 156.72 & 30.12 & 33.19 \\
\hline & v.c & 220.24 & 226.15 & 163.50 & 165.22 & 33.74 & 37.22 \\
\hline & Mix & 212.72 & 215.33 & 155.26 & 158.70 & 31.53 & 35.04 \\
\hline \multirow{4}{*}{$\begin{array}{l}75 \% \\
\text { NPK }\end{array}$} & 0 & 232.33 & 234.66 & 174.62 & 177.82 & 34.56 & 39.62 \\
\hline & C & 242.70 & 244.50 & 180.46 & 182.56 & 36.48 & 42.12 \\
\hline & v.c & 252.46 & 256.33 & 192.36 & 194.16 & 39.09 & 46.36 \\
\hline & Mix & 247.50 & 250.12 & 186.44 & 186.92 & 37.74 & 44.08 \\
\hline \multirow{4}{*}{$\begin{array}{l}100 \% \\
\text { NPK }\end{array}$} & 0 & 237.00 & 240.13 & 178.00 & 180.33 & 34.92 & 40.62 \\
\hline & C & 257.66 & 260.80 & 204.62 & 207.12 & 43.52 & 50.16 \\
\hline & v.c & 268.20 & 272.33 & 218.45 & 222.37 & 47.30 & 55.66 \\
\hline & Mix & 264.23 & 266.20 & 212.33 & 216.66 & 45.15 & 52.99 \\
\hline \multicolumn{2}{|c|}{$F$ test } & $* * *$ & $* * *$ & $* * *$ & $* \star *$ & ** & $* \star *$ \\
\hline \multicolumn{2}{|c|}{ LSD at $0.05 \%$} & 2.66 & 1.88 & 0.163 & 0.442 & 0.554 & 0.256 \\
\hline
\end{tabular}

2- Integrated effect of inorganic and organic fertilizers on leaves chlorophyll content.

Chlorophyll content of maize leaves i.e. chl. $a$, chl. $b$ and chl. $a+b$ values as affected by inorganic and organic fertilizers in the two successive summer seasons were shown in Table 4. Application of inorganic NPK fertilizers at $100 \%$ RD recorded the highest values of chl. a $(0.275,0.283)$; chl. b $(0.100,0.103)$ and chl. $a+b(0.374,0.386)$ in the two 
investigated summer seasons of 2020 and 2021, respectively. These results are in agreement with those found by Hussain et al., (2007).

Application of inorganic NPK fertilizers increase chlorophyll content where $N$ fertilizer increases the availability of important nutrients as $P$,
$\mathrm{Ca}$ and $\mathrm{Mg}$ for chlorophyll production (Khan et al., 2011). Phosphorus has an effective role in chlorophyll synthesis and enhancement photosynthesis process in plant. In addition, potassium has important role in control stomotal guard cells of leaves and increasing photosynthesis (Hussain et al., 2007).

Table 4. Integrated effect of inorganic and organic fertilizers on chlorophyll content of maize leaves in the two successive seasons under investigation.

\begin{tabular}{|c|c|c|c|c|c|c|c|}
\hline \multirow{3}{*}{\multicolumn{2}{|c|}{ Treatments }} & \multicolumn{6}{|c|}{ Chlorophyll contents $\mathrm{mg} \cdot \mathrm{g}^{-1} \mathrm{FWt}$} \\
\hline & & \multicolumn{2}{|c|}{ Chl. A } & \multicolumn{2}{|c|}{ Chl. B } & \multicolumn{2}{|c|}{ Chl. $a+b$} \\
\hline & & $1^{\text {st }}$ & $2^{\text {nd }}$ & $1^{\text {st }}$ & $2^{\text {nd }}$ & $1^{\text {st }}$ & $2^{\text {nd }}$ \\
\hline \multicolumn{8}{|c|}{ Main : inorganic fertilizer rates } \\
\hline \multicolumn{2}{|c|}{0} & 0.244 & 0.246 & 0.068 & 0.070 & 0.312 & 0.316 \\
\hline \multicolumn{2}{|c|}{50} & 0.252 & 0.256 & 0.080 & 0.082 & 0.332 & 0.339 \\
\hline \multicolumn{2}{|c|}{75} & 0.265 & 0.273 & 0.092 & 0.096 & $0 . .357$ & 0.369 \\
\hline \multicolumn{2}{|c|}{100} & 0.275 & 0.283 & 0.100 & 0.103 & 0.374 & 0.386 \\
\hline \multicolumn{2}{|c|}{ F test } & $\star \star \star *$ & $\star \star * \star$ & $\star \star \star *$ & $\star * * *$ & $\star \star * *$ & 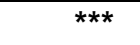 \\
\hline \multicolumn{2}{|c|}{ LSD at $0.05 \%$} & 0.004 & 0.004 & 0.002 & 0.004 & 0.004 & 0.003 \\
\hline \multicolumn{8}{|c|}{ Sub main: organic fertilizer sources } \\
\hline \multicolumn{2}{|c|}{0} & 0.251 & 0.257 & 0.078 & 0.081 & 0.329 & 0.339 \\
\hline \multicolumn{2}{|c|}{ C } & 0.257 & 0.263 & 0.084 & 0.086 & 0.342 & 0.349 \\
\hline \multicolumn{2}{|c|}{ V.C } & 0.264 & 0.271 & 0.090 & 0.093 & 0.355 & 0.365 \\
\hline \multicolumn{2}{|c|}{ Mix } & 0.262 & 0.267 & 0.087 & 0.090 & 0.349 & 0.357 \\
\hline \multicolumn{2}{|c|}{ F test } & $\star \star \star *$ & $\star \star * \star$ & $* *$ & $\star \star * *$ & $\star \star * *$ & 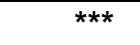 \\
\hline \multicolumn{2}{|c|}{ LSD at $0.05 \%$} & 0.003 & 0.003 & 0.004 & 0.003 & 0.005 & 0.006 \\
\hline \multicolumn{8}{|c|}{ Interaction } \\
\hline \multirow{4}{*}{0 NPK } & 0 & 0.239 & 0.242 & 0.060 & 0.066 & 0.299 & 0.308 \\
\hline & $\mathbf{C}$ & 0.242 & 0.244 & 0.068 & 0.070 & 0.310 & 0.314 \\
\hline & V.C & 0.250 & 0.253 & 0.074 & 0.075 & 0.324 & 0.328 \\
\hline & Mix & 0.247 & 0.246 & 0.070 & 0.070 & 0.317 & 0.316 \\
\hline \multirow{4}{*}{$\begin{array}{l}50 \% \\
\text { NPK }\end{array}$} & 0 & 0.245 & 0.250 & 0.076 & 0.078 & 0.321 & 0.328 \\
\hline & C & 0.252 & 0.254 & 0.079 & 0.081 & 0.331 & 0.335 \\
\hline & V.C & 0.258 & 0.263 & 0.084 & 0.086 & 0.342 & 0.349 \\
\hline & Mix & 0.256 & 0.260 & 0.081 & 0.084 & 0.337 & 0.344 \\
\hline \multirow{4}{*}{$\begin{array}{l}75 \% \\
\text { NPK }\end{array}$} & 0 & 0.258 & 0.266 & 0.088 & 0.092 & 0.346 & 0.358 \\
\hline & C & 0.263 & 0.270 & 0.090 & 0.094 & 0.353 & 0.364 \\
\hline & V.C & 0.271 & 0.280 & 0.097 & 0.102 & 0.368 & 0.382 \\
\hline & Mix & 0.268 & 0.277 & 0.094 & 0.098 & 0.362 & 0.375 \\
\hline \multirow{4}{*}{$\begin{array}{l}100 \% \\
\text { NPK }\end{array}$} & 0 & 0.265 & 0.280 & 0.088 & 0.090 & 0.353 & 0.362 \\
\hline & $\mathrm{C}$ & 0.274 & 0.272 & 0.101 & 0.101 & 0.375 & 0.385 \\
\hline & V.C & 0.280 & 0.290 & 0.107 & 0.112 & 0.387 & 0.402 \\
\hline & Mix & 0.279 & 0.284 & 0.104 & 0.110 & 0.383 & 0.396 \\
\hline \multicolumn{2}{|c|}{$F$ test } & ** & $* *$ & $* *$ & $* *$ & ** & $* *$ \\
\hline \multicolumn{2}{|c|}{ LSD at $0.05 \%$} & 0.009 & 0.007 & 0.009 & 0.008 & 0.010 & 0.012 \\
\hline
\end{tabular}


Organic V.C. fertilizer application achieved the highest values of chlorophyll content comparing with other organic fertilizers treatments application where it recorded chl. $(a+b)$ with values $(0.355,0.365)$, mix recorded values $(0.349$, $0.357)$ and $C$ recorded values $(0.342$, 0.349 ) in the both tested seasons. Same results were found by Sigaye et al., (2021).

Chlorophyll content values attained with vermicompost (V.C.) were higher than those recorded by compost (C.) where it contains macro and micronutrients more than those found in compost especially $\mathbf{N}$ which increases chlorophyll content and improves photosynthesis process (Sayfallah et al., 2015).

The combination of inorganic NPK fertilizers at $100 \%$ RD and organic V.C. fertilizer achieved the highest values of chl. a $(0.280,0.290)$, chl. b $(0.107,0.112)$ and chl. $a+b(0.387,0.402)$ in the two investigated successive seasons. Those results may be due to the positive effect of inorganic and organic fertilizers in supplying plants with nutrients which are responsible for chlorophyll production and promoting photosynthesis process (Abd El-Gawad and Morsy, 2017). Addition of inorganic NPK at $75 \%$ or $100 \%$ in combination with either organic compost or vermicompost gave values higher than that recorded by inorganic NPK at $100 \%$ RD.

3- Integrated effect of inorganic and organic fertilizers on yield and yield attributes.

Results recorded in Table 5 show influence of inorganic and organic fertilizers on grain yield (ton fed ${ }^{-1}$ ) and some yield attributes such as plant height (cm); ear length (cm); ear diameter (cm); ear weight (g) and 100 kernel weight (g). All tested treatments had significant effects on grain yield and most of yield attributes of maize in the two seasons under investigation. Using inorganic NPK fertilizers at $100 \%$ RD gave the highest values of plant height (299.08, 302.91); ear length $(20.10,20.26)$; ear diameter $(4.38,4.25)$, ear weight (225.71, 229.29), 100 kernel weight (54.77, $58.22)$ and grain yield $(3.32,3.34)$ of maize in the two investigated seasons, respectively. The same result was found by EI Fouly et al., (2012). Increasing yield and yield attributes as the addition of inorganic NPK fertilizers may be due to the facts of their effective roles in increasing plant growth and enhancing plant photosynthesis. Moreover, $\mathrm{K}$ has a responsible role in activating some enzymes important for several physiological plant processes (Olowoboko et al., 2017).

Organic fertilizers sources also positively affected on yield and yield attributes of maize in the two seasons. The highest values of plant height $(270.49,273.91)$; ear length $(18.80,19.01)$; ear diameter (4.22, 4.41); ear weight (201.11, 203.95); 100 kernel weight (47.24, $52.80)$ and grain yield $(2.98,3.01)$ in the two seasons, respectively were observed plants treated with organic V.C. fertilizers. The same findings were found by Deepak et al., (2018), Sifolo et al. (2019) and Jagwe et al. (2020) who concluded that the application of organic fertilizer improved soil fertility as well as the growth and yield characters. The increments recorded by organic fertilizers comparing with control were explained based on the effective roles of compost and vermicompost on improving soil properties and increasing availability of nutrients. Consequently, increasing plant growth, yield and yield attributes (Laekemariam and Gidago, 2012). 


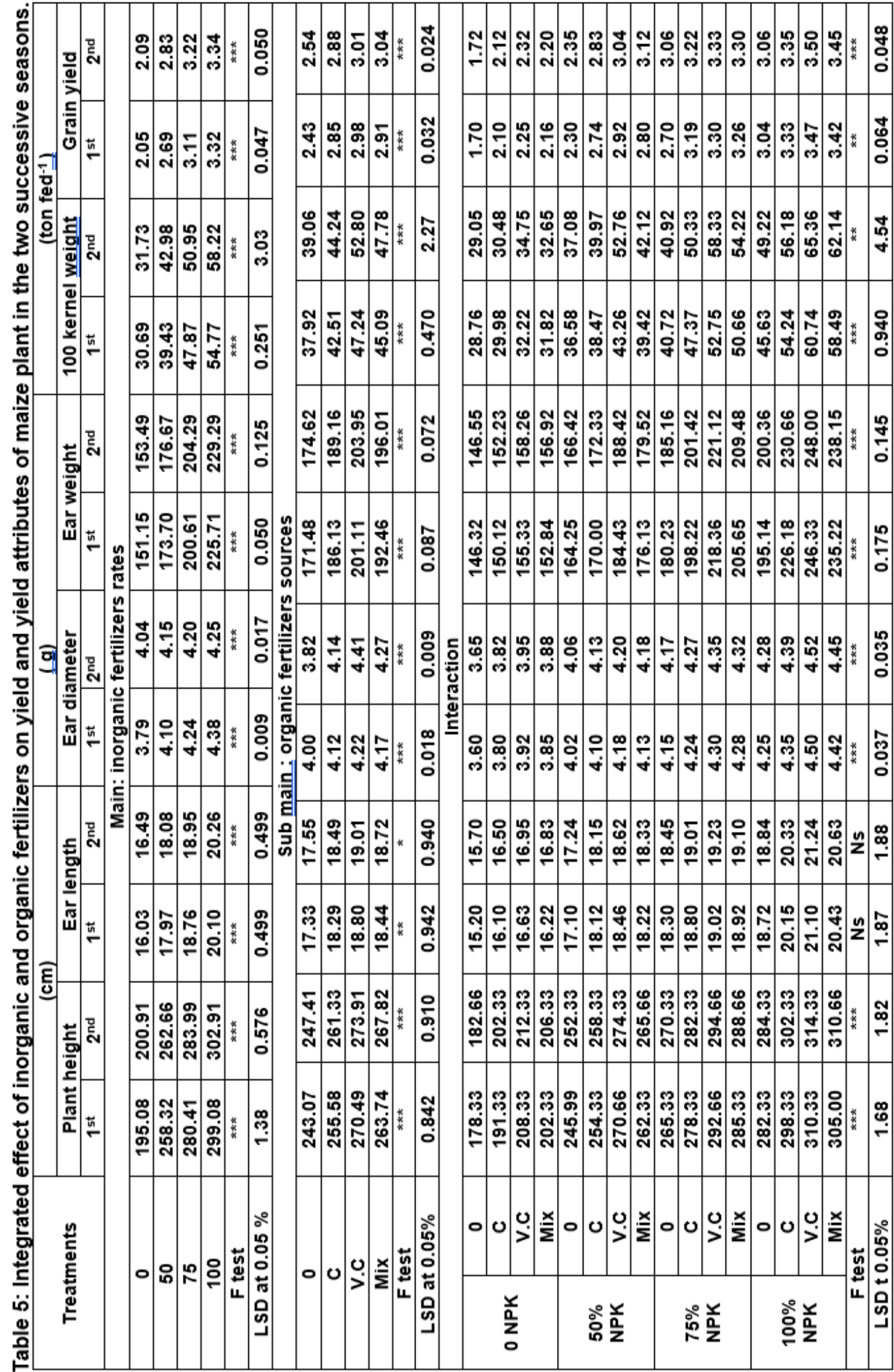


Combination of inorganic NPK fertilizers at $100 \%$ RD and organic V.C. fertilizer recorded the highest values of maize grain yield and yield attributes in the both tested seasons followed by NPK at $100 \% \mathrm{RD}$ and C , NPK at $75 \% \mathrm{RD}$ and V.C and lately NPK at $75 \% \mathrm{RD}$ and $\mathrm{C}$ treatments comparing with the application of inorganic NPK fertilizers at $100 \%$ RD singly, this result may be attributed to the positive effect of inorganic NPK fertilizers on vegetative growth parameters and chlorophyll content as mentioned before. V.C. also has a responsible role in improving the growth and crop development. Fanuel and Gifole, (2013) also found that application of compost at $5 \mathrm{t} \mathrm{ha}^{-1}$ with urea was better than application of $10 t$ ha $^{-1}$ of compost plus urea. Also, Zeinab et al., (2014) concluded that the combination of vermicompost with nitrogen fertilizers was better than the addition of nitrogen fertilizers alone. The same result was also concluded by Kandil et al., (2020).

\section{4- Integrated effect of inorganic and organic fertilizers on NPK concentrations.}

Results presented in Table 6, Figs (1 to 4) show the impact of inorganic and organic fertilizers treatments on NPK concentrations in maize leaves at maximum growth vegetative stage and grain under the two investigated successive seasons, respectively.

All treatments significantly affected on NPK concentrations in maize leaves and grains. Using inorganic NPK fertilizers at $100 \%$ RD gave the highest values of NPK concentrations where the values of $\mathrm{N}$ were $(3.57,3.61)$ in leaves and were $(2.63$, $2.75)$ in grains; values of $P$ were $(0.394$, $0.396)$ in leaves and were $(0.266,0.271)$ in grains and values of $K$ were $(2.92,2.97)$ in leaves and were $(2.67,2.71)$ in grains in the two tested seasons, respectively. These results were in accordance with that found by Olowoboko et al., (2017).
Increasing the levels of inorganic NPK fertilizers applied increase $N, p$ and $K$ availability in the soil and consequently increase their concentrations within plant, on the other hand increasing $N$ fertilizer dose increase $P$ concentration (Nahidah et al., 2002). Potassium fertilizer application also impact on nitrate uptake and transport within the plant which may be the reason for increasing nitrogen concentration within plant (Bruns and Ebelhar, 2006).

Organic fertilizers application also increased NPK concentration in maize leaves and grains comparing with nonaddition. In this concern organic V.C. treatment recorded the highest values of $N(3.35,3.42)$ in leaves and $(2.47,2.55)$ in grains; values of $P(0.367,0.371)$ in leaves and $(0.243,0.248)$ in grains and values of $\mathrm{K}(2.72,2.75)$ in leaves and $(2.45,2.51)$ in grains in 2020 and 2021 seasons, respectively. These results are in matching with those observed by (Sigaye et al., 2021). Vermicompost is faster decomposition, higher nutrients content, much finer structure than compost and also it releases nutrients faster and in more available forms for plant uptake (Erdal et al., 2018). On the other hand, releasing of organic acids from vermicompost through organic matter decay solubilize fixed phosphorus from $\mathrm{Fe}$ and $\mathrm{Al}$ complexes in the soil (Yadvinder et al., 2010).

Both compost and vermicompost are organic materials sources that improve the soil physical, chemical and biological properties. In addition, they supply the soil with high quantities of available nutrients. Consequently nutrient concentrations within the plant increase (Jagwe et al., 2020). Organic fertilizers supply the soil with more nutrients in available forms and produce organic and inorganic acids during decomposition which reduce the soil $\mathrm{pH}$ and promote the solubility and availability of $N, P$, and $\mathrm{K}$ (Erdal et al., 2018). 
Table 6. Individual effect of inorganic and organic fertilizers on NPK concentrations of maize leaves and grains in the two successive seasons.

\begin{tabular}{|c|c|c|c|c|c|c|c|c|c|c|c|c|}
\hline \multirow[t]{4}{*}{ Treatments } & \multicolumn{12}{|c|}{ Nutrients concentrations (\%) } \\
\hline & \multicolumn{4}{|c|}{$\mathbf{N}$} & \multicolumn{4}{|c|}{$\mathbf{P}$} & \multicolumn{4}{|c|}{$\mathbf{K}$} \\
\hline & \multicolumn{2}{|c|}{ Leaves } & \multicolumn{2}{|c|}{ Grains } & \multicolumn{2}{|c|}{ Leaves } & \multicolumn{2}{|c|}{ Grains } & \multicolumn{2}{|c|}{ Leaves } & \multicolumn{2}{|c|}{ Grains } \\
\hline & $1^{\text {st }}$ & $2^{\text {nd }}$ & $1^{\text {st }}$ & $2^{\text {nd }}$ & $1^{\text {st }}$ & $2^{\text {nd }}$ & $1^{\text {st }}$ & $2^{\text {nd }}$ & $1^{\text {st }}$ & $2^{\text {nd }}$ & $1^{\text {st }}$ & $2^{\text {nd }}$ \\
\hline \multicolumn{13}{|c|}{ Main : inorganic fertilizers rates } \\
\hline 0 & 2.69 & 2.76 & 2.04 & 2.09 & 0.297 & 0.304 & 0.191 & 0.196 & 2.18 & 2.21 & 1.92 & 2.01 \\
\hline 50 & 3.18 & 3.24 & 2.28 & 2.37 & 0.347 & 0.353 & 0.220 & 0.224 & 2.55 & 2.59 & 2.26 & 2.30 \\
\hline 75 & 3.43 & 3.47 & 2.50 & 2.59 & 0.377 & 0.383 & 0.250 & 0.253 & 2.80 & 2.83 & 2.52 & 2.56 \\
\hline 100 & 3.57 & 3.61 & 2.63 & 2.75 & 0.394 & 0.396 & 0.266 & 0.271 & 2.92 & 2.97 & 2.67 & 2.71 \\
\hline F test & *** & *** & *** & *** & *** & *** & *** & *** & *** & *** & *** & *** \\
\hline $\begin{array}{c}\text { LSD } \\
\text { at } 0.05 \%\end{array}$ & 0.047 & 0.024 & 0.046 & 0.047 & 0.004 & 0.005 & 0.004 & 0.002 & 0.047 & 0.024 & 0.044 & 0.025 \\
\hline \multicolumn{13}{|c|}{ Sub main : organic ferilizers sources } \\
\hline 0 & 3.02 & 3.06 & 2.22 & 2.32 & 0.337 & 0.343 & 0.217 & 0.221 & 2.46 & 2.52 & 2.19 & 2.25 \\
\hline C & 3.22 & 3.28 & 2.35 & 2.44 & 0.351 & 0.356 & 0.232 & 0.235 & 2.60 & 2.64 & 2.34 & 2.38 \\
\hline V.c & 3.35 & 3.42 & 2.47 & 2.55 & 0.367 & 0.371 & 0.243 & 0.248 & 2.72 & 2.75 & 2.45 & 2.51 \\
\hline Mix & 3.28 & 3.33 & 2.41 & 2.49 & 0.361 & 0.365 & 0.236 & 0.240 & 2.66 & 2.69 & 2.38 & 2.43 \\
\hline F test & *** & *** & $* * *$ & $* * *$ & $* \star *$ & *** & $* * *$ & *** & *** & *** & *** & $\star \star * *$ \\
\hline $\begin{array}{c}\text { LSD at } \\
0.05 \%\end{array}$ & 0.043 & 0.043 & 0.044 & 0.043 & 0.004 & 0.003 & 0.004 & 0.005 & 0.043 & 0.047 & 0.047 & 0.047 \\
\hline
\end{tabular}

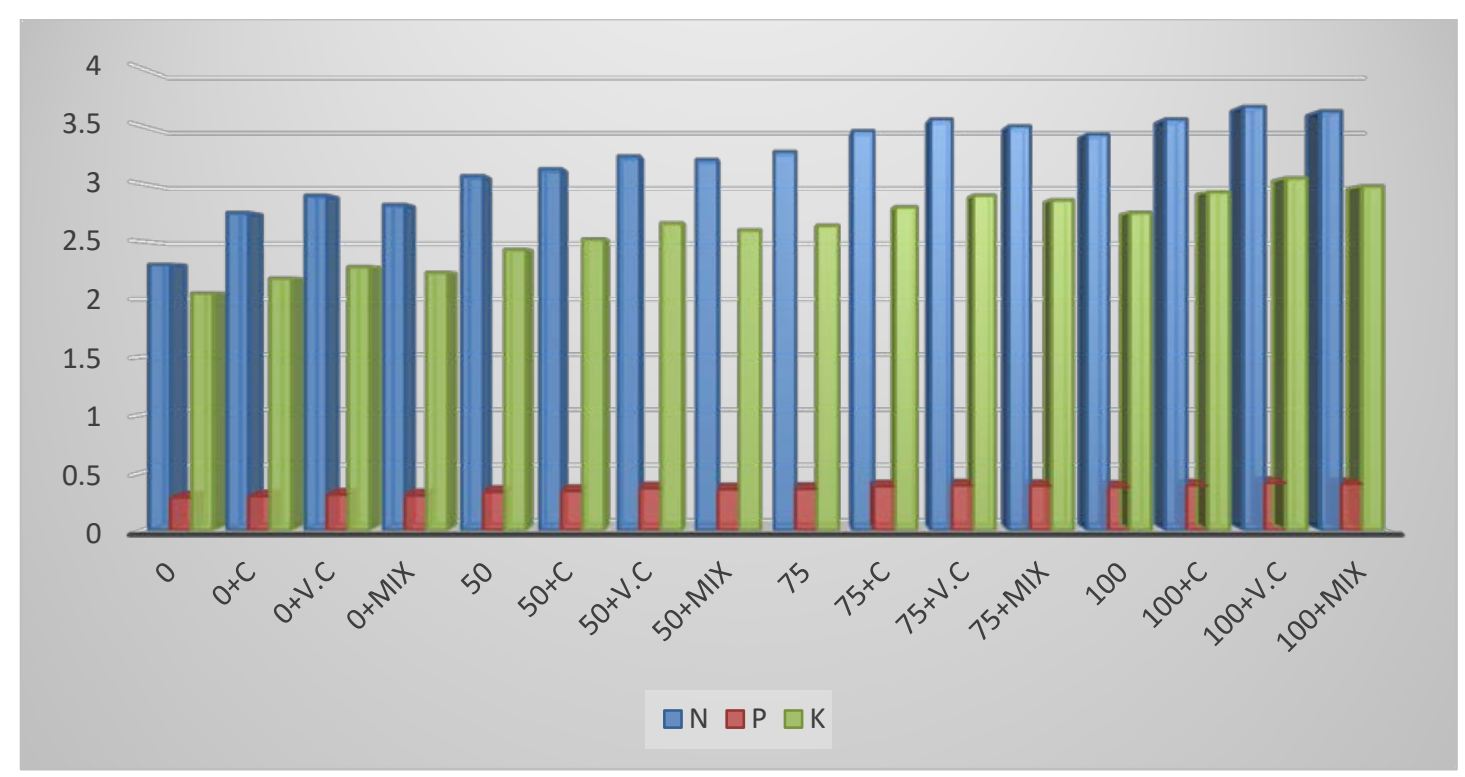

Fig 1: Interaction effect of inorganic and organic fertilizers on NPK concentrations in maize leaves at 2020 season. 
Enas E. Yousif, Eman H. Abd El-Azeiz, et al.,

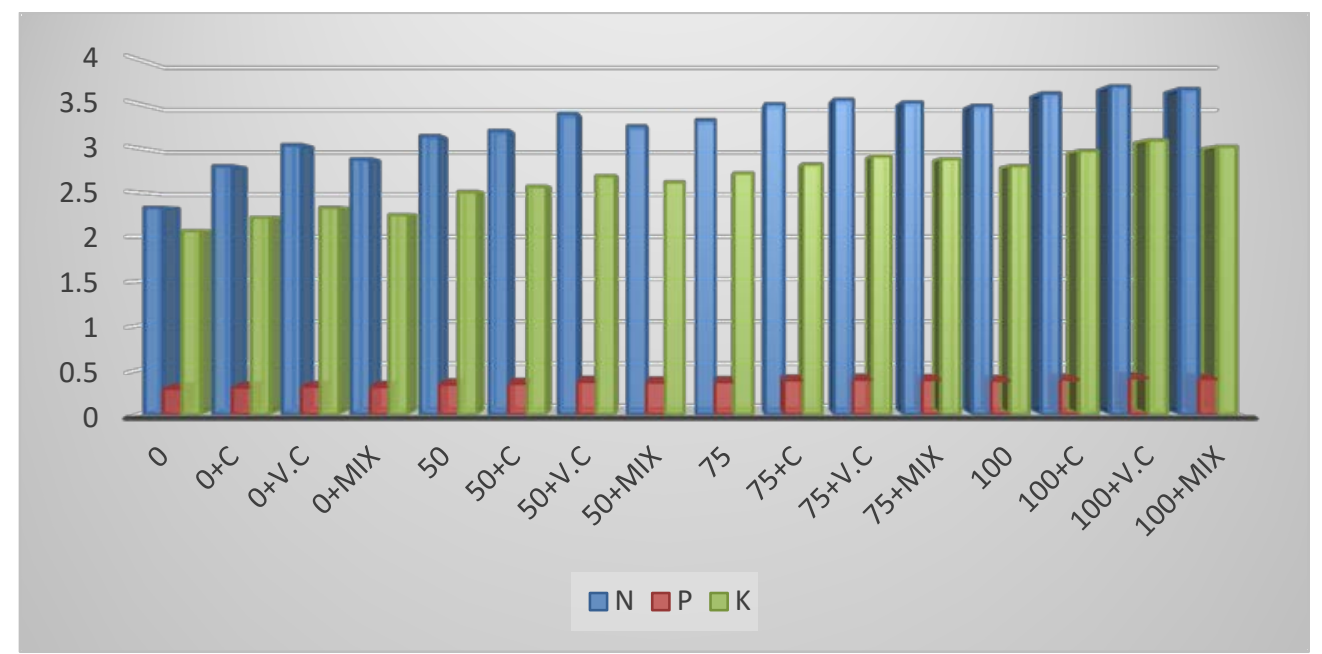

Fig 2: Interaction effect of inorganic and organic fertilizers on NPK concentrations in maize leaves at 2021 season.

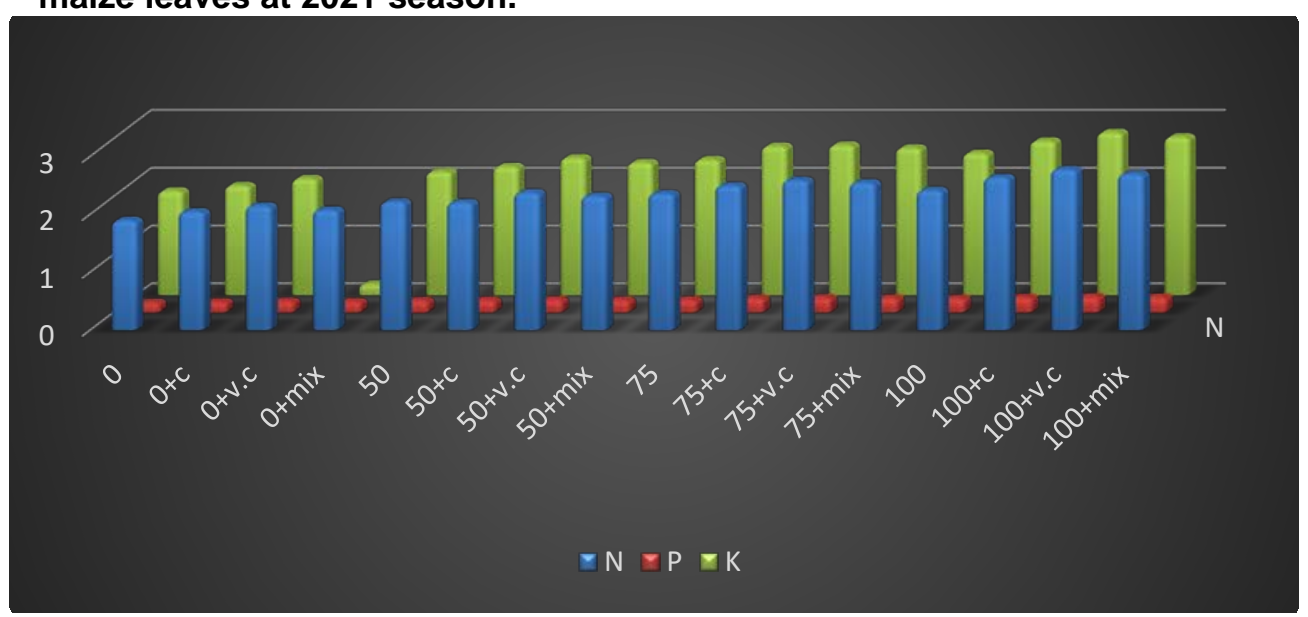

Fig 3: Interaction effect of inorganic and organic fertilizers on NPK concentrations in maize grains at 2020 season.

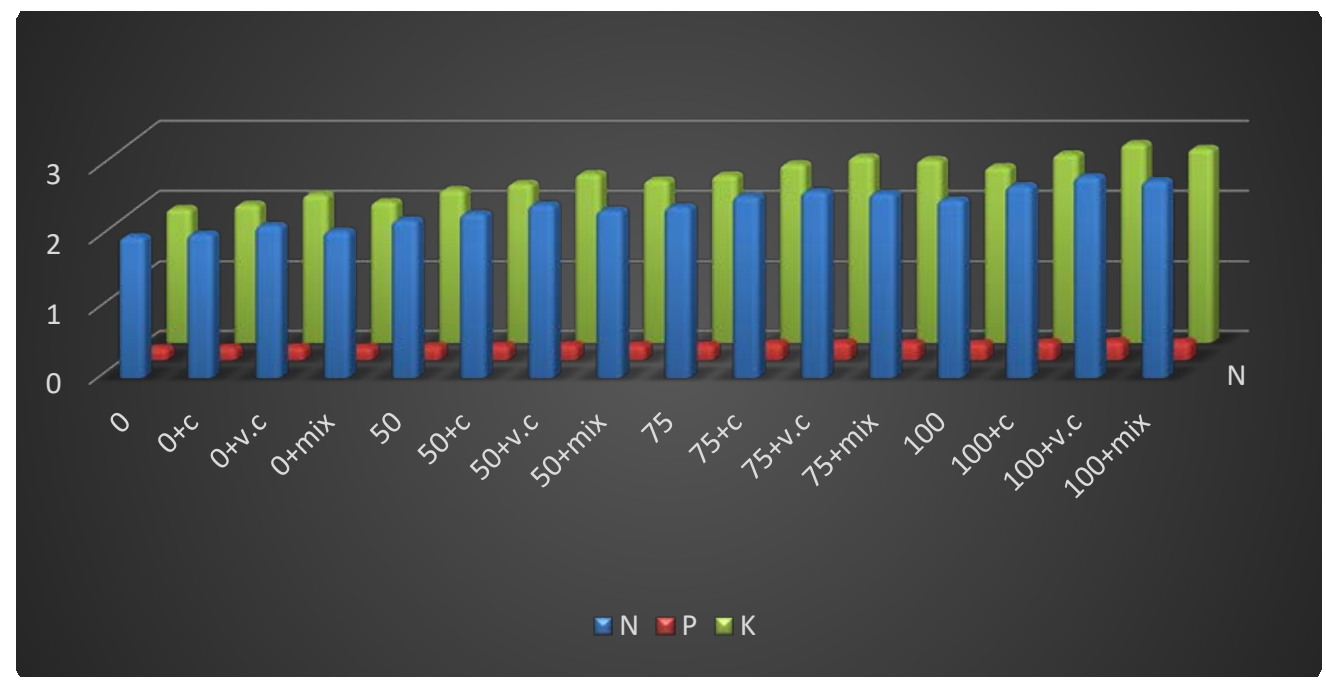

Fig 4: Interaction effect of inorganic and organic fertilizers on NPK concentrations in maize grains at 2021 season. 
Application of inorganic NPK fertilizers at $100 \%$ RD together with organic V.C. fertilizer gave the highest values of NPK concentration in leaves and grains of maize during the two investigated seasons comparing with the addition of in organic NPK fertilizers at $100 \%$ RD only.

The interaction of inorganic and organic fertilizers improve soil properties, increase nutrients availability in the soil and cause balance between them. As a result, nutrients concentrations within plant increase (Djawu, 2017). The same results were concluded by (El Mantawy et al., 2021).

\section{5- Integrated effect of inorganic and} organic fertilizers on NPK uptake

Data in Table 7 show that the application of inorganic and organic fertilizers positively affected on N, P and $K$ uptake by maize grains in the both seasons. In this respect, the addition of inorganic NPK fertilizer at 100\% RD recorded the highest values of $\mathrm{N}, \mathrm{P}$ and $\mathrm{K}$ uptake by maize grains in the two successive seasons namely $(87.90,92.05)$ for $\mathrm{N}$ uptake , $(8.88,9.06)$ for $\mathrm{P}$ uptake and $(89.14,90.80)$ for $K$ uptake comparing with the control treatment. These results were corresponding to those attained by (El Fouly et al., 2012).

Application of organic fertilizers i.e. compost (C), vermicompost (V.C.) and the mix also increased $N, P$ and $K$ uptake by maize grains in the two investigated seasons. These increments may be attributed to slow releasing of nutrients from organic fertilizer in available forms (Zaremanesh et al., 2017).

Compost release nitrogen in
ammonium ions form while
vermicompost release the same mineral
in nitrate form, in addition to releasing of
bicarbonate ions from organic matter
decomposition that increase P

availability in the soil via displacement of phosphate by organic acids produced during organic manure decomposition (Joshi and Sharma, 2010).

The highest values of $\mathbf{N}(74.95,78.94)$, $P(7.38,7.40)$ and $K(74.65,77.81)$ uptake by maize grains in the two seasons were achieved by organic V.C. fertilizer application. The same result was found by (Sigaye et al., 2021).

The combination of inorganic NPK fertilizers at $100 \%$ RD and organic V.C. fertilizer treatment achieved the highest values of $N, P$ and $K$ uptake by maize grains during the two successive seasons comparing with their addition at $100 \%$ RD singly, these results are in matching with that recorded by ElMantawy et al., (2021).

6- Integrated effect of inorganic and organic fertilizers on available NPK in the soil after harvesting.

Data presented data in Table 8 show the impact of the inorganic and organic fertilizers on available $N, P$ and $K$ in the soil after maize harvesting in the both seasons. Soil fertility is the main controlling factor in agricultural production (El-Gamal, 2015). Using of inorganic NPK fertilizers at $100 \%$ RD achieved the highest values of available $N$ (47.88, 49.59), $P(10.25,10.31)$ and $K$ $(221.13,229.89)$ in the both seasons, respectively at the post harvesting maize. The same result was found by (Abd ElGawad and Morsy, 2017).

Compost and vermicompost should be applied before planting to take a sufficient time for natural oxidation of organic material that enhances the soil available nutrients (Erdal et al., 2018). Application of organic fertilizers i.e. compost (C), vermicompost (V.C.) and mix of them increase the available nutrients $N, P$ and $K$ in the soil via improving soil properties, increasing soil 
Enas E. Yousif, Eman H. Abd El-Azeiz, et al.,

CEC through raising the exchange sites numbers for available nutrients, promoting soil quality via increasing microbial activity and improving soil fertility (Jagwe et al., 2020). Application of organic compost fertilizer recorded the highest values of available $\mathrm{N}(46.23$, 47.49); $p(9.85,10.03)$ and $K(216.82$, 224.83) in the soil after maize harvesting in 2020 and 2021, respectively. This result is in harmony with that found by Laekemariam and Gidago, (2012).

Table 7. Integrated effect of inorganic and organic fertilizers on NPK uptake by maize grains in the two successive seasons.

\begin{tabular}{|c|c|c|c|c|c|c|c|}
\hline \multirow{3}{*}{\multicolumn{2}{|c|}{ Treatments }} & \multicolumn{6}{|c|}{ Nutrients uptake $\left(\mathrm{Kg} \mathrm{fed}^{-1}\right)$} \\
\hline & & \multicolumn{2}{|c|}{$\mathbf{N}$} & \multicolumn{2}{|c|}{$\mathbf{P}$} & \multicolumn{2}{|c|}{$\mathbf{K}$} \\
\hline & & $1^{\text {st }}$ & $2^{\text {nd }}$ & $1^{\text {st }}$ & $2^{\text {nd }}$ & $1^{\text {st }}$ & $2^{\text {nd }}$ \\
\hline \multicolumn{8}{|c|}{ Main : inorganic fertilizer rates } \\
\hline \multicolumn{2}{|c|}{0} & 42.17 & 43.79 & 3.94 & 4.11 & 39.73 & 42.16 \\
\hline \multicolumn{2}{|c|}{50} & 61.51 & 67.46 & 5.93 & 6.39 & 61.06 & 65.56 \\
\hline \multicolumn{2}{|c|}{75} & 78.00 & 83.72 & 7.81 & 8.20 & 78.67 & 82.77 \\
\hline \multicolumn{2}{|c|}{100} & 87.90 & 92.05 & 8.88 & 9.06 & 89.14 & 90.80 \\
\hline \multicolumn{2}{|c|}{ F test } & $* * *$ & $\star \star \star *$ & $* * *$ & $* \star *$ & $\star \star \star *$ & 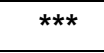 \\
\hline \multicolumn{2}{|c|}{ LSD at $0.05 \%$} & 1.42 & 1.87 & 0.224 & 0.277 & 1.91 & 1.45 \\
\hline \multicolumn{8}{|c|}{ Sub main: organic fertilizer sources } \\
\hline \multicolumn{2}{|c|}{0} & 55.16 & 60.20 & 5.40 & 5.76 & 54.55 & 58.76 \\
\hline \multicolumn{2}{|c|}{ C } & 68.14 & 71.50 & 6.76 & 6.92 & 68.40 & 69.82 \\
\hline \multicolumn{2}{|c|}{ V.C } & 74.95 & 78.94 & 7.38 & 7.40 & 74.65 & 77.81 \\
\hline \multicolumn{2}{|c|}{ Mix } & 71.33 & 76.38 & 7.02 & 7.67 & 71.00 & 74.89 \\
\hline \multicolumn{2}{|c|}{ F test } & $* \star \star$ & *** & $* \star *$ & $* \star *$ & $* * *$ & $* * *$ \\
\hline \multicolumn{2}{|c|}{ LSD at $0.05 \%$} & 1.44 & 1.29 & 0.295 & 0.252 & 1.62 & 1.53 \\
\hline \multirow{4}{*}{0 NPK } & 0 & 32.31 & 34.76 & 3.06 & 3.18 & 30.78 & 33.04 \\
\hline & C & 43.06 & 43.65 & 3.96 & 4.06 & 39.91 & 41.95 \\
\hline & v.c & 48.39 & 50.55 & 4.54 & 4.86 & 45.46 & 49.20 \\
\hline & Mix & 44.91 & 46.21 & 4.20 & 4.35 & 42.75 & 44.45 \\
\hline \multirow{4}{*}{$\begin{array}{l}50 \% \\
\text { NPK }\end{array}$} & 0 & 51.04 & 53.09 & 4.87 & 5.04 & 49.23 & 51.44 \\
\hline & C & 60.57 & 66.48 & 5.97 & 6.28 & 61.11 & 64.50 \\
\hline & v.c & 69.47 & 75.37 & 6.71 & 7.11 & 69.47 & 73.58 \\
\hline & Mix & 64.97 & 74.89 & 6.19 & 7.12 & 64.41 & 72.71 \\
\hline \multirow{4}{*}{$\begin{array}{l}75 \% \\
\text { NPK }\end{array}$} & 0 & 63.70 & 74.95 & 6.10 & 7.04 & 63.43 & 73.45 \\
\hline & C & 79.73 & 83.73 & 8.13 & 8.30 & 82.31 & 82.41 \\
\hline & v.c & 85.45 & 89.07 & 8.64 & 8.87 & 85.81 & 88.73 \\
\hline & Mix & 83.11 & 87.13 & 8.38 & 8.57 & 83.11 & 86.47 \\
\hline \multirow{4}{*}{$\begin{array}{l}100 \% \\
\text { NPK }\end{array}$} & 0 & 73.58 & 78.01 & 7.59 & 7.79 & 74.76 & 77.12 \\
\hline & C & 87.92 & 92.14 & 8.85 & 9.04 & 88.89 & 90.43 \\
\hline & v.c & 96.48 & 100.78 & 9.64 & 9.86 & 97.83 & 99.73 \\
\hline & Mix & 92.35 & 97.27 & 9.30 & 9.59 & 93.72 & 95.92 \\
\hline \multicolumn{2}{|c|}{ F test } & $* * *$ & $* * *$ & ** & * & ** & $* *$ \\
\hline \multicolumn{2}{|c|}{ LSD at $0.05 \%$} & 2.88 & 2.59 & 0.591 & 0.505 & 3.25 & 3.06 \\
\hline
\end{tabular}


Table 8. Integrated effect of inorganic and organic fertilizers on available NPK in the soil after maize harvesting in the two successive seasons.

\begin{tabular}{|c|c|c|c|c|c|c|c|}
\hline \multirow{3}{*}{\multicolumn{2}{|c|}{ Treatments }} & \multicolumn{6}{|c|}{ Available nutrients in the soil ( $\mathrm{mg} \mathrm{Kg}^{-1}$ soil) } \\
\hline & & \multicolumn{2}{|c|}{$\mathbf{N}$} & \multicolumn{2}{|c|}{$\mathbf{P}$} & \multicolumn{2}{|c|}{$\mathrm{K}$} \\
\hline & & $1^{\text {st }}$ & $2^{\text {nd }}$ & $1^{\text {st }}$ & $2^{\text {nd }}$ & $1^{\text {st }}$ & $2^{\text {nd }}$ \\
\hline \multicolumn{8}{|c|}{ Main : inorganic fertilizer rates } \\
\hline \multicolumn{2}{|c|}{0} & 39.94 & 40.76 & 8.27 & 8.51 & 202.56 & 205.19 \\
\hline \multicolumn{2}{|c|}{50} & 45.92 & 46.82 & 9.52 & 9.64 & 215.40 & 220.03 \\
\hline \multicolumn{2}{|c|}{75} & 46.86 & 48.02 & 9.91 & 10.01 & 217.71 & 225.03 \\
\hline \multicolumn{2}{|c|}{100} & 47.88 & 49.59 & 10.25 & 10.31 & 221.13 & 229.89 \\
\hline \multicolumn{2}{|c|}{ F test } & $* * *$ & $* * *$ & $* * *$ & $* * *$ & $* * *$ & *** \\
\hline \multicolumn{2}{|c|}{ LSD at $0.05 \%$} & 0.149 & 0.442 & 0.070 & 0.040 & 0.028 & 212.23 \\
\hline \multicolumn{8}{|c|}{ Sub main: organic fertilizer sources } \\
\hline \multicolumn{2}{|c|}{0} & 43.25 & 43.96 & 8.82 & 8.90 & 209.35 & 212.23 \\
\hline \multicolumn{2}{|c|}{ C } & 46.23 & 47.49 & 9.85 & 10.03 & 216.82 & 224.83 \\
\hline \multicolumn{2}{|c|}{ V.C } & 45.68 & 47.03 & 9.71 & 9.84 & 215.65 & 222.10 \\
\hline \multicolumn{2}{|c|}{ Mix } & 45.45 & 46.71 & 9.58 & 9.71 & 214.97 & 220.97 \\
\hline \multicolumn{2}{|c|}{ F test } & $\star * \star *$ & $\star \star \star *$ & $* \star *$ & $\star * \star *$ & $\star \star * \star$ & $\star \star \star *$ \\
\hline \multicolumn{2}{|c|}{ LSD at $0.05 \%$} & 0.133 & 0.373 & 0.029 & 0.045 & 0.045 & 0.039 \\
\hline \multicolumn{8}{|c|}{ Interaction } \\
\hline \multirow{4}{*}{0 NPK } & 0 & 38.10 & 38.22 & 7.84 & 7.92 & 198.70 & 198.97 \\
\hline & C & 41.16 & 42.15 & 8.54 & 8.94 & 205.36 & 209.46 \\
\hline & V.c & 40.38 & 41.53 & 8.40 & 8.67 & 203.14 & 206.22 \\
\hline & Mix & 40.15 & 41.16 & 8.33 & 8.53 & 203.05 & 206.12 \\
\hline \multirow{4}{*}{$50 \%$ NPK } & 0 & 44.24 & 44.62 & 9.02 & 9.12 & 209.40 & 211.50 \\
\hline & C & 48.81 & 47.92 & 9.83 & 9.97 & 218.18 & 226.01 \\
\hline & V.c & 46.48 & 47.56 & 9.70 & 9.84 & 217.48 & 222.18 \\
\hline & Mix & 46.18 & 47.18 & 9.53 & 9.66 & 216.55 & 220.43 \\
\hline \multirow{4}{*}{ 75\% NPK } & 0 & 44.90 & 46.18 & 9.15 & 9.21 & 211.54 & 215.66 \\
\hline & C & 47.86 & 48.94 & 10.34 & 10.47 & 220.59 & 229.63 \\
\hline & V.c & 47.51 & 48.63 & 10.16 & 10.23 & 219.78 & 227.92 \\
\hline & Mix & 47.19 & 48.36 & 10.02 & 10.16 & 218.94 & 226.94 \\
\hline \multirow{4}{*}{$\begin{array}{l}100 \% \\
\text { NPK }\end{array}$} & 0 & 45.76 & 46.82 & 9.27 & 9.36 & 217.79 & 222.82 \\
\hline & C & 49.12 & 50.96 & 10.71 & 10.76 & 223.15 & 234.22 \\
\hline & V.c & 48.36 & 50.43 & 10.59 & 10.63 & 222.23 & 232.11 \\
\hline & Mix & 48.30 & 50.16 & 10.45 & 10.50 & 221.37 & 230.42 \\
\hline \multicolumn{2}{|c|}{$F$ test } & $\star *$ & $*$ & $\star \star * *$ & $\star * *$ & $* * *$ & $* * *$ \\
\hline \multicolumn{2}{|c|}{ LSD at $0.05 \%$} & 0.266 & 0.746 & 0.059 & 0.090 & 0.091 & 0.078 \\
\hline
\end{tabular}

The addition of inorganic NPK at $100 \%$ RD and organic compost fertilizers simultaneously gave the highest values of available $N, P$ and $K$ in the soil after harvesting in the two seasons comparing with application of inorganic NPK fertilizers at $100 \%$ RD only. The result is in matching with that concluded by
Adamu et al., (2015) and El Mantawy et al., (2021).

7-Integrated effect of inorganic and organic fertilizers on benefit: cost ratio.

Economics of maize as affected by inorganic and organic fertilizers have been given in Table (9). The highest total 
Enas E. Yousif, Eman H. Abd El-Azeiz, et al.,

cost of cultivation $\left(£\right.$. fed $\left.^{-1}\right)$ was noticed with all treatments of V.C. followed by mix treatments. The cost of cultivation for control (no fertilizer application) was $6500 \mathrm{E}$. $\mathrm{fed}^{-1}$ however, the cost of inorganic NPK fertilizers at RD was 8955 £. $\mathrm{fed}^{-1}$. This clears that vermin compost treatments recorded more cost of cultivation than other treatments. The maximum gross incomes namely 17350 and $17500 \mathrm{E}$. fed $^{-1}$ of maize crop in the two seasons under study, respectively were recorded when the application of V.C. and NPK at $100 \%$ RD simultaneously followed by the treatment of mix and NPK at $100 \%$ RD with gross incomes of 17100 and $17250 \mathrm{E}$. fed $^{-1}$ in 2020 and 2021seasons, respectively. Yet, the gross incomes for the treatment of NPK at RD were 15200 and $15300 £$. fed ${ }^{-1}$ in the two tested seasons. On the other hand, all treatments of organic fertilizers in combination with inorganic NPK fertilizers at $75 \%$ RD achieved gross income more than using NPK at $100 \%$ RD singly.

The highest net returns namely 6795 and $6895 £$. fed ${ }^{-1}$ were obtained when the application of NPK at $100 \%$ RD and C. followed by the treatment of NPK at $75 \%$ RD and C with net returns 6584 and $67354 \mathrm{E}_{\mathrm{f}} \mathrm{fed}^{-1}$ in the two investigated seasons. The lowest net return 2000 and $2100 £$. fed ${ }^{-1}$ noticed in control treatments (without NPK fertilizers addition). It noticed that V.C. treatments recorded the lowest net returns comparing with the other organic fertilizers applications.

The highest B: C ratios (1.70 and 1.7) were recorded from combination of NPK at $75 \% \mathrm{RD}$ and compost followed by the application of NPK at $100 \%$ RD with 1.69 and $1.70 \mathrm{~B}: \mathrm{C}$ ratio. The $\mathrm{B}: \mathrm{C}$ ratios of control treatment were 1.30 and 1.32 for the two investigated seasons, respectively.

Table 9. Costs of cultivation, gross and net returns, and benefit: cost ratios of different treatments.

\begin{tabular}{|c|c|c|c|c|c|c|c|c|c|}
\hline \multirow{2}{*}{\multicolumn{2}{|c|}{ Treatments }} & \multicolumn{2}{|c|}{$\begin{array}{l}\text { Total cost of } \\
\text { cultivation } \\
\left(£ . \mathrm{fed}^{-1}\right)\end{array}$} & \multicolumn{2}{|c|}{$\begin{array}{l}\text { Gross return } \\
\quad\left(£^{\prime} \text { fed }^{-1}\right)\end{array}$} & \multicolumn{2}{|c|}{$\begin{array}{l}\text { Net return } \\
\left(\boldsymbol{E}^{\prime} \text { fed }^{-1}\right)\end{array}$} & \multicolumn{2}{|c|}{$\begin{array}{l}\text { Benefit cost } \\
\text { ratio (BCR) }\end{array}$} \\
\hline & & $1^{\text {st }}$ & $2^{\text {nd }}$ & $1^{\text {st }}$ & $2^{\text {nd }}$ & $1^{\text {st }}$ & $2^{\text {nd }}$ & $1^{\text {st }}$ & $2^{\text {nd }}$ \\
\hline \multirow{4}{*}{0 NPK } & 0 & 6500 & 6500 & 8500 & 8600 & 2000 & 2100 & 1.30 & 1.32 \\
\hline & C & 7400 & 7400 & 10500 & 10600 & 3100 & 3200 & 1.41 & 1.43 \\
\hline & V.C & 9000 & 9000 & 11250 & 11600 & 2250 & 2600 & 1.25 & 1.28 \\
\hline & Mix & 8200 & 8200 & 10800 & 11000 & 2600 & 2800 & 1.31 & 1.34 \\
\hline \multirow{4}{*}{$\begin{array}{l}50 \% \\
\text { NPK }\end{array}$} & 0 & 7978 & 7978 & 11500 & 11750 & 3522 & 3772 & 1.44 & 1.47 \\
\hline & C & 8878 & 8878 & 13700 & 14150 & 4822 & 5272 & 1.54 & 1.59 \\
\hline & V.C & 10478 & 10478 & 14600 & 15200 & 4122 & 4722 & 1.39 & 1.45 \\
\hline & Mix & 9678 & 9678 & 14000 & 15600 & 4322 & 5922 & 1.44 & 1.61 \\
\hline \multirow{4}{*}{$\begin{array}{l}75 \% \\
\text { NPK }\end{array}$} & 0 & 8466 & 8466 & 13500 & 15300 & 5034 & 6834 & 1.59 & 1.60 \\
\hline & C & 9366 & 9366 & 15950 & 16100 & 6584 & 6734 & 1.70 & 1.71 \\
\hline & V.C & 10966 & 10966 & 16500 & 16650 & 5534 & 5684 & 1.50 & 1.51 \\
\hline & Mix & 10166 & 10166 & 16300 & 16500 & 6134 & 6334 & 1.60 & 1.62 \\
\hline \multirow{4}{*}{$\begin{array}{l}100 \% \\
\text { NPK }\end{array}$} & 0 & 8955 & 8955 & 15200 & 15300 & 6245 & 6345 & 1.69 & 1.70 \\
\hline & C & 9855 & 9855 & 16650 & 16750 & 6795 & 6895 & 1.68 & 1.69 \\
\hline & V.C & 11455 & 11455 & 17350 & 17500 & 5895 & 6045 & 1.51 & 1.52 \\
\hline & Mix & 10655 & 10655 & 17100 & 17250 & 6445 & 6595 & 1.60 & 1.61 \\
\hline
\end{tabular}


The costs of cultivation for all vermicompost treatments were higher than the other organic fertilizers treatments because of price of V.C. where $5000 £$ ton $^{-1}$, while compost price is 180 E.ton $^{-1}$. On the other hand, compost enhanced seed yield and recorded the highest net return.

Among organic fertilizers treatments there were much differences in $\mathrm{B}$ : $\mathrm{C}$ ratio and organic compost treatment recorded the highest net return and $B$ : C ratio. The combination of organic compost fertilizer and inorganic NPK at $75 \%$ RD could be the best alternative compared with the other treatments and viable option for enhancing crop yield and farmers income.

\section{CONCLUSION}

This study recommends the addition of nitrogenous, phosphate and potassium fertilizers to the corn crop at rates of $75 \%$ of the recommended in combination with organic compost fertilizer due to the highest economic return as well as the highest and best productivity of the corn crop, in addition to that this treatment is an alternative and effective solution to add duration The major nutrients (nitrogen, phosphorous and potassium) at $100 \%$ of the recommended rates. That is, it provides $25 \%$ of the added mineral fertilizer, increases the productivity of the corn crop and improves its quality.

\section{REFERENCES}

Abd El-Gawad, A. M. and A. S. M. Morsy (2017). Integrated impact of organic and inorganic fertilizers on growth, yield of maize (Zea mays L.) and soil properities under Upper Egypt conditions. J. Plant Production, Mans. Univ., 8 (11): 1103-1112.
Adamu, U. K., P. J. Mrema and J. J. Msaky (2015). Growth response of maize (Zea mays L.) to different rates of nitrogen, phosphorus and farm yard manure in Morogoro Urban District,Tanzania. American $\mathrm{J}$. of Experimental Agriculture 9(2): 1-8.

Adetiminrin, V. O., I. Vroh-Bi, A. Menkir, S. E. Mitchell and S. Kresovich (2008). Diversity analysis of elite maize inbred lines adapted to West and Central Africa using SSR markers. Maydica. Journal of Crop Science and Biotechnology, 53: 199-207.

Atiyeh, R. M., C. A. Edwards, J. D. Metzer, S. Lee and N. Q. Arancon (2002). The influence of humic acids derived from earth warm- processed organic wastes on plant growth. Bioresource Technol. 84:7-14.

Bastida, F., T. Hermandez and C. Garcia (2010). Soil degradation and rehabilitation: Microorganisms and Functionality. In:I, H., Franke - Whittle, I., Goberna, M., (Eds), Microbes at work. Springer Heidelberg Dordrecht London New York. Pp.253 - 270.

Bruns, H. A and M. W. Ebelhar (2006). Nutrient uptake of maize affected by nitrogen and potassium fertility in a humide sub tropical environment. Communication in Soil Science and Plant Analysis. 37: 275-293.

Buresh, R. J., E. R. Austin and E. T. Craswell (1982). Analytical methods in $\mathrm{N}-15$ research. Fertilizer research 3: 37-62.

Chapman, H. D. and P. Pratt (1961). Methods of Analysis for Soils, Plants and Waters. Division of Agric. Sci. Univ. of California, USA.

Cottenie, A., M. Verloo, L. Kiekens, G. Velgh and R. Amerlynck (1982). Chemical analysis of plant and soils. State Univ., Ghent, Belgium. 
Deepak, K. N. Meena, J. P. Singh, A. Shori, R. meena and M. Bohi (2018). Effect of different organic sources on growth, yield and quality of rainfed maize (Zea mays L.)+ Guava (Psidium guajava L.) based agri-horti system. J.of Pharmacogonsy and Phytochemistry. 7(4): 2125-2129.

Dignac, M. F., D. Derrien, P. Barré, S. Barot, L. Cécillon, C. Chenu, T. Chevallier, G. T. Freschet, P. Garnier, B. Gue-net, M. Hedde, K. Klumpp, G. Lashermes, P. A. Maron, N. Nunan, C. Roumet and D. I. Basile (2017). Increasing soil carbon storage: mechanisms, effects of agricultural practices and proxies. A review. Agron Sustain Dev 37: 14.

Djawu, B. P. (2017). Compost and nitrogen fertilizer on maize (Zea mays L.) growth and yield and residual effects on cowpea (Vigna unguiculata (L.) Walp) in a rotatiuon. Master of $P$ hilosophy in Crop Science Degree, Ghana University.

Edwards, C. A., J. Dominguez and N. Q. Arancon (2004). The influence of vermicompost on plant growth and pest incidence. In: Soil Zoology for Sustainable Development in the 21st century (Shakir S.H., Mikhail Mikhail W.Z.A., eds) Self-Publisher, Cairo, Egypt. pp. 396-419.

El- Fouly, M. M., E. A. A. Abou El-Nour, S. H. A. Shaaban and M. S. Zeidan (2012). Effect of different levels of NPK and micronutrients fertilization on yield and nutrient uptake of maize plants. Journal of American Science, 8(8): 209-2014.

El Gamal, B. A. H. (2015). Effect of some soil amendments on soil conditions and plant growth. Ph.D. Thesis Fac. of Agric., Menoufia Univ., Egypt.

El- Mantawy, R. F., E. H. Abd El-Azeiz and I. A. I. El-Gazzar (2021). Response of maize to combination of organic and mineral nitrogen fertilization on growth, productivity and soil properties under calcareous and alluvial soil. Plant Cell Biotechnology and Molecular Biology. 22(37\&38): 183-198.

Erdal, I., A. Dogan, C. Yaylaci and P. Alaboz (2018). Comparing the effects of compost and vermicompost on corn growth, nutrients concentration and uptake during the different growth periods. Scientific papers. Series A. Agronomy, vol., LXI, No. I, 2285-2785.

Fageria, N. K. and V. C. Baligar (2005). Enhancing nitrogen use efficiency in crop plants. Advances in Agronomy 88: 97-185.

Fanuel, L. and G. Gifole (2013). Growth and yield response of maize (zea mays L.) to variable rates of compost and inorganic fertilizer integration in Wolaita, southern Ethiopia. Am. J. Plant Nutr. Fert. Technol., 3(2):43-52.

FAO (2009). "Food Insecurity: When people must live with hunger and fear starvation." The State of Food Insecurity in the World. Rome: The Food and Agriculture Organization of the United Nations. Vol. 12.

Gao, M.; F., Liang, A. Yu, B., Li and L. Yang (2010). Evaluation of stability and maturity during forced-aeration of chicken manure and sawdust at different $\mathrm{C} / \mathrm{N}$ ratios. Chemosphere, ELSEVIER, 78 (5): 614-619.

Hafesz, E. M. and Kh. A. A. Abdelaal (2015). Impact of nitrogen fertilization levels on morphological characters and yield quality of some maize hybrids (Zea mays L.) . Egypt. J. Agron. 37(1): 35-48.

Hussain, N., A. Z. Khan, H. Akbar, N. G. Bangash, Z. H. Khan and M. Idress (2007). Response of maize varities to phosphorus and potassium levels. Sarhad J. Agric. 23(4): 881-887.

Jagwe, J., K. Chelimo, J. J. Karungi, A. Kamakech J. and Lederer (2020). 
Comparative performance of organic fertilizer in maize growth, yield and economic results. Agronomy. 10, 69.

Joshi, N. and S. Sharma (2010). Physiochemical characterization of sulphidation pressmud composted pressmud and vermicomposted pressmud. Environ. Sci. 2(3): 223-264.

Kandil, E. E., N. R. Abd elsalam, M. A. Mansour, H. M. Ali and M. H. Siddiqui (2020). Potentials of organic manure and potassium forms on maize growth and production. Scientific Reports. 10:8752.

Khan, H. Z., A. Iqbal, N. Akbar and D. L. Jones (2011). Response of maize (Zea mays $L$.) varieties to different levels of nitrogen. Crop \&Environment. 2(2):1519.

Klute, A. (1986). Methods of Soil Analysis. Part-1: Physical and Mineralogical Methods (2nd). Amer. Soc. Agron. Madison. Wisconsin. U.S.A.

Laekemariam, F. and G. Gidago (2012). Response of maize (Zea mays L.) to integrated fertilizer application in Wolaita, South Ethiopia. Advance Life Sci. Technology. 5:21-30.

Makinde, E. A. and O. T. Ayoola (2010). Growth, yield and NPK uptake by maize with complementary organic and inorganic fertilizers. Article in African Journal of Food Agriculture Nutrition and Development. Vol.10 No.3.

Nahidah, B., A. M. Saeed, M. Seema, ULH., Mahmood, Ur-RA, Habib and A. Mohammad (2002). Influence of urea application on growth, yield and mineral uptake in two corn (Zea mays L.) cultivars. African Journal of Biotechnology. 11(46):10494-10503.

Nayek, S., I. H. Choudhury, N. Jaishee and S. Roy (2014). Spectrophotometric analysis of chlorophylls and carotenoids from commonly grown fern species by various extracting solvents. Res. Jour. of chem. Sciences, 4(9): 63-69.

Olowoboko, T.B., O. O. Onasanya, O. T. Salami and J. O. Azeez (2017). Growth and uptake in maize as influenced by NPK fertilizer in green house experiment. International Journal of Plant \& Soil Science. 17(3):1-10.

Page, A. L., R. H. Miller and D. R. Keeney (1982). Methods of Soil Analysis. Part2: Chemical and Microbiological Properties. (2nded.) American Society of Agronomy, Madison, Wisconsin. USA.

Rai Mangla (2006). Effect of integrated nutrient management local and hybrid varieties of maize (Zea mays L.) yield. Hand Book of Agriculture. 2006, 872 886.

Ramasamy, P. K. and B. Kathirvelu (2011). Influence of vermicompost on kernel yield of Maize (Zea mays L.). J. Curr. Microbiol. App. Sci.2018.7 (2): 1405-1410.

Sayfallah, A., O. Maysam and F. Ebrahim (2015). Effect of vermicompost and triple super phosphate on yield of corn (Zea mays L.) in Behbahan. J. Exper. Bio. and Agric. Sci. 3(VI): 495499.

Sifolo, S. C., I. K. Kouadio, K. K. Kouamé and I. A.Z. Bi (2019). Effect of compost from different animal matures on maize (Zea mays) growth. J. Exp. Biol. and Agric. Sci., 7(2) : 178 $-185$.

Sigaye, M. H., R. Mekuria, K. Kebede, A. Nigussei and B. Lulie (2021). Integrated use of organic and inorganic fertilizers on maize (Zea mays L.) yield and soil fertility in Andisols soil of Sidama, Ethiopia. Asian J. of Plant Science and Research. 11(1): 10-18.

Singh, R. N., R. Sulatiya and K.R. S. A. Ghata (2003). Effect of higher 
application of Nitrogen and potassium over recommended level on growth yield and yield attribute of late sown winter maize (Zea mays L.) Crop Research, Hissar. 2003; 26(1):71-74.

Sinha, R. K., S. A. Agarwal, K. Chaudhan and D. Valani (2010). The wonders of earth worms and its vermicomposting in farm production: Charles Darwin's friends of farmers', with potential to replace destructive chemical fertilizers from agriculture. Agric. Sci. 1(2): 7694.

Snedecor, G.W. and W.G. Cochran (1980). Statistical Methods. 7th ed. Iowa State Univ. Press, lowa, USA.

Steel, R. G. D. and J. H. Torrie (1984). Principles and procedures of statistics. 2nd ed. McGraw Hill Book Co. Inc. Singapore, pp. 172-177.

Yadvinder, S. R. K., S. J. K. Bijay, J. S. Gupta, B. Ladha and Jagmohansing (2010). Evaluation of pressmud cake as a source of nitrogen and phosphorus for rice-wheat cropping system in the Indo-Gangetic plains of India. 44(5): 755-762.

Zaremanesh, H., B. Nasiri and A. Amiri (2017). The effect of vermicompost biological fertilizer on corn yield. J. Mater. Environ. Sci. 8(1): 154-159.

Zeinab, A. B., Z. Hossein and R. Masoud (2014). Effect of Vermicompost and Chemical Fertilizers on Growth Parameters of three Corn Cultivars. J. Applied Sci. and Agric., 9(9): 22-26. 
التأثير الكمى والكيفى لبعض الأسمدة الغير عضوية و العضوية على نبات الأرة تحت الأراضى الرسوبية

ايناس السعيد يوسف ، ايمان حمدى عبد العزيز ، كرم السيد محمد نصار

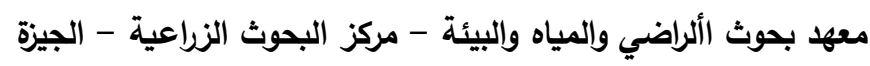

الملخص العربي

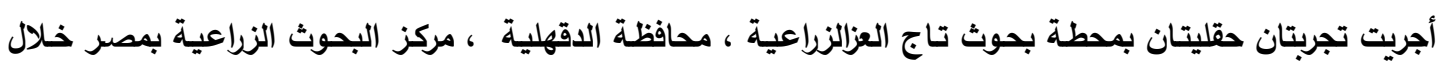

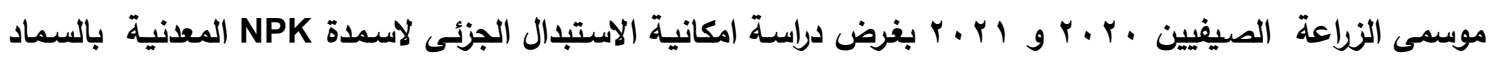

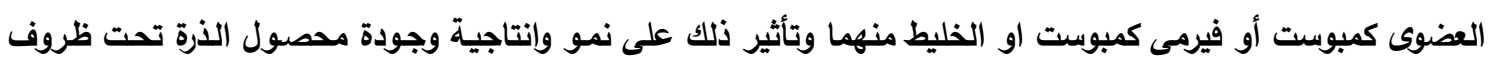
الاراضى الرسوبية .

لذلك صممت التجربة بنظام القطع المنشقة مره واحدة فى ثلاث مكررات حيث شغلت القطع الرئيسية باربعة معدلات

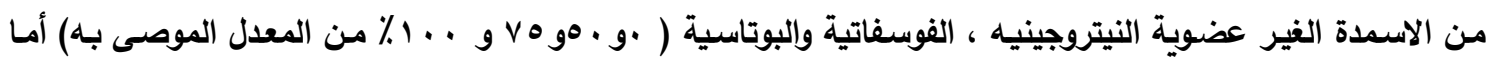

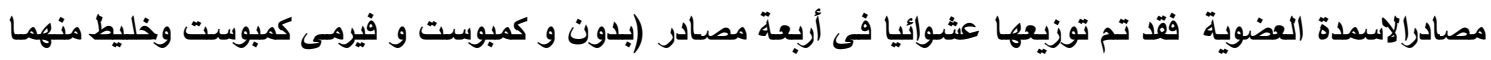

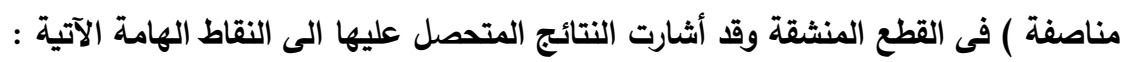

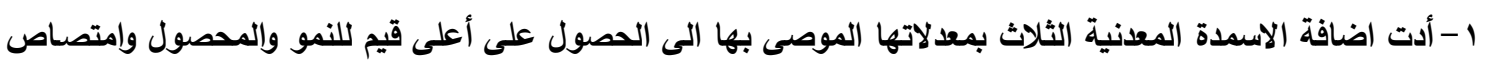
العناصر الغذائيه ץ-كان لاستخدام الاسمدة العضويه موضع الدراسة (الكمبوست او الفيرمى كمبوست او الخليط منهما) تأثير معنوى على الفى

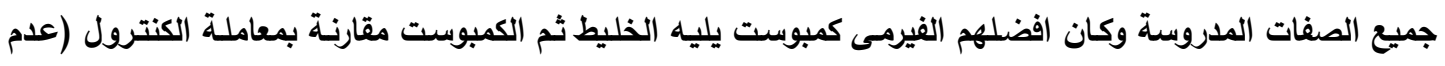

(ضافة الاسمدة المعدنية)

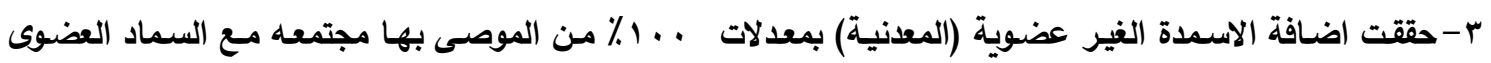

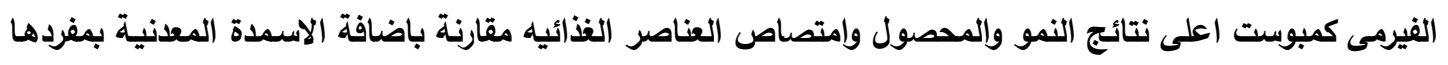

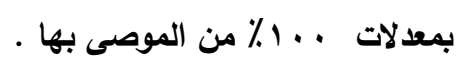

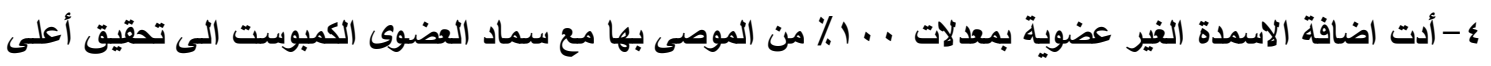

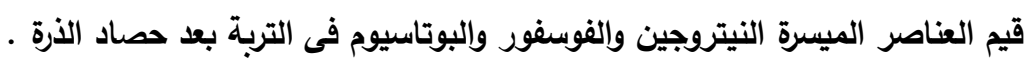
ه-حققت معاملات الكمبوست أعلى عوائد اقتصادية

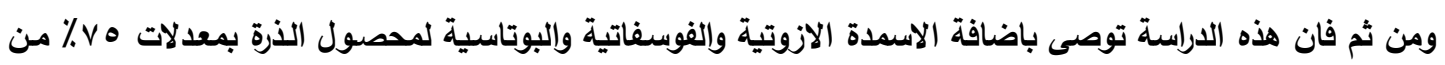

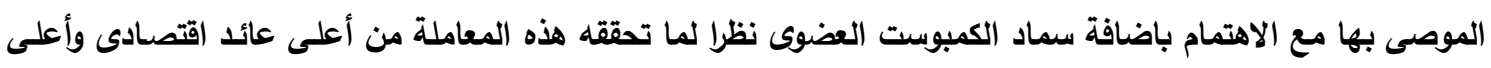

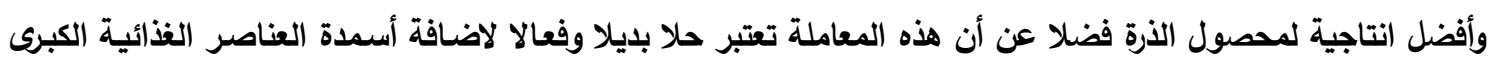

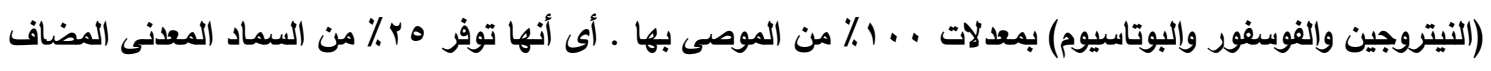

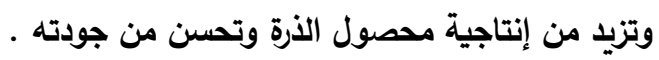

$$
\begin{aligned}
& \text { أسماء السادة المحكمين } \\
& \text { أ. أد /مضان إسماعيل كنانى رئيس معهد بحوث الأراضى والمياه والبيئة - مركز البحوث الزراعية }
\end{aligned}
$$

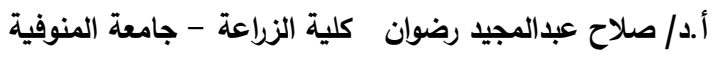

